\title{
The Edwin Smith Surgical Papyrus: An analysis of the first case reports of spinal cord injuries
}

\author{
J. Trevor Hughes, MD \\ Department of Neuropathology, Radcliffe Infirmary, Oxford, OX2 6HE, UK.
}

The Edwin Smith Surgical Papyrus occupies the first place of a remarkable list of records. It is clearly the first documentation of cases of spinal cord injuries, but it is also the first medical document concerned with cases of injuries. It is the first known important medical treatise and also the first known record that can be called a scientific document. Those of us concerned with the management or the scientific investigation of human spinal cord injuries have a particular interest in this first of all medical and scientific textbooks. The document is incomplete but a major part of that which has survived is concerned with the investigation and management of cases of injury to the spinal cord. The details of the discovery of this papyrus by Edwin Smith and its translation by James Henry Breasted (Breasted, 1922a, 1922b, and 1930) are of comparable interest to the indentity of the ancient original author and the later copyist whose artistic work has survived in this document. A later translation into German was made by Westendorf (1966).

\section{Edwin Smith, the original owner of the Papyrus}

Edwin Smith (Fig. 1) was a remarkable man and for several reasons the naming of this papyrus after him is justified. He was born in Connecticut in the year 1822, a memorable year in modern Egyptology being that in which Champollion succeeded in deciphering the hierogylphic script. Edwin Smith went to Egypt in about the year 1858, having previously studied the Egyptian language and culture in London and Paris, thus being one of the earliest modern students of Ancient Egypt. He spent a large part of his adult life in Egypt and, from 1858 to 1876, lived and worked in Luxor, near Thebes. He seems to have been as much a dealer as a scholar of the surviving culture of Ancient Egypt (Adams, 1870). Unfortunately for his eventual reputation, he published little or nothing of his considerable experience of the new science of Egyptology. He had a prodigious knowledge of hieratic texts and amongst his posthumous papers was a praiseworthy attempt at a complete translation of the papyrus which now bears his 


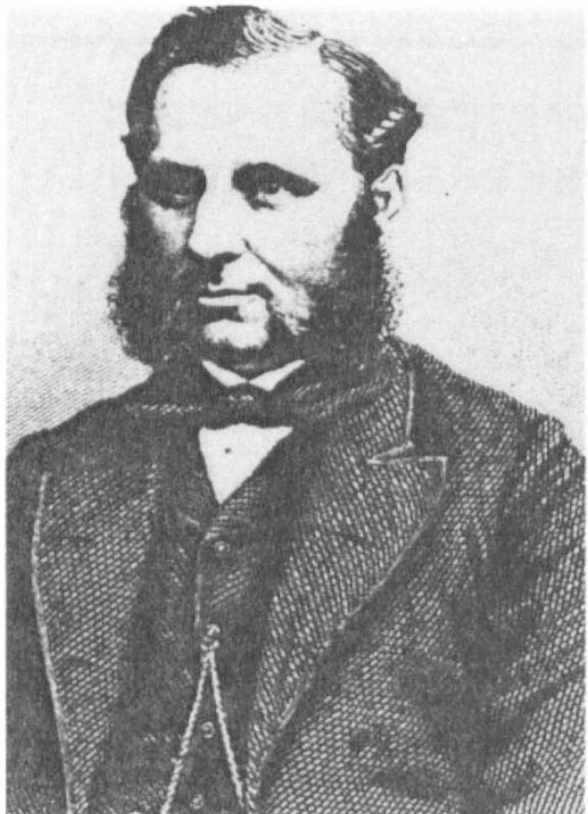

Fig. 1

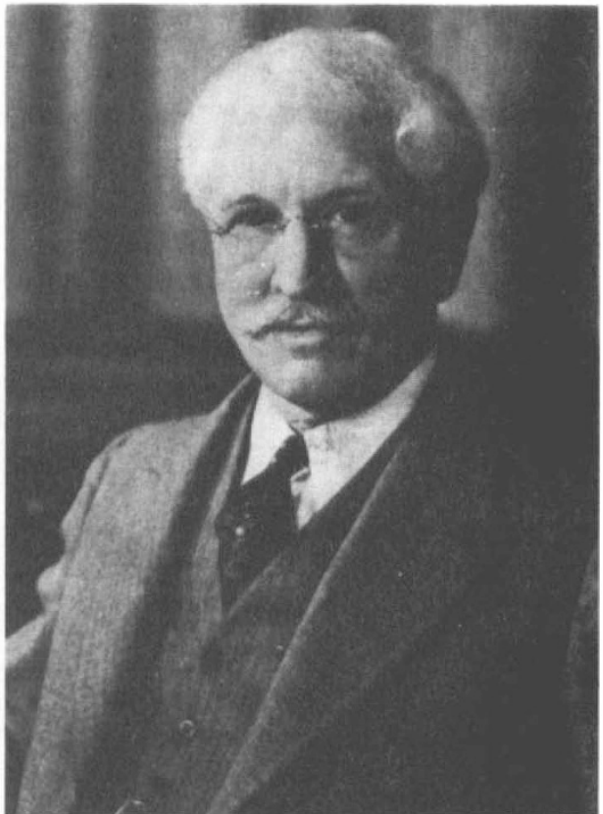

Fig. 2

Figure 1 Edwin Smith, reproduction of an engraving. (By kind permission of the Radio Times Hulton Picture Library).

Figure 2 James Henry Breasted. Studio photograph of the famous Archeologist and founder of the School of Oriental Studies in Chicago.

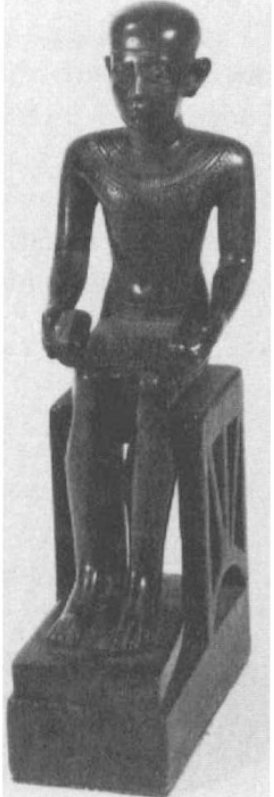

Fig. 3



Fig. 4

Figure 3 Imhotep, famous Architect, Scientist and Physician, a legendary figure of the Old Kingdom period, and of an earlier date than the Edwin Smith Surgical Papyrus. Photograph of a statuette in the Ashmolean Museum, Oxford.

Figure 4 Scribe depicted as taking dictation from the God Thoth. Photograph of a statuette in the Musée du Louvre. 
name, a remarkable achievement considering the current state of knowledge of hieratic in the decade from 1860 to 1870 . Edwin Smith studied many papyri and the now named Ebers papyrus, which was briefly referred to as the Smith papyrus, passed through his hands. His purchase of the Edwin Smith Surgical Papyrus will be described later.

\section{James Henry Breasted the translator of the Papyrus}

James Henry Breasted (Fig. 2) was the first academically trained Egyptologist in America and the founder of the Oriental Institute in Chicago. He was entrusted with the papyrus by the New York Historical Society in 1920, published two brief notes on the papyrus in 1922, and then after a long period of study and analysis, in the year 1930 published the papyrus in a magnificent facsimile edition with a hieroglyphic transcription and translation.

\section{The original Egyptian author}

The ancient original author of the text can only be the subject of our speculation. As with Homer and the Iliad and the Odyssey, the main source of information is in the text itself, although the language and form of the document give some clues. The text provides information about the date of the original author and also an assessment of his medical expertise. The date of the original compilation can be assessed approximately from clues in the vocabulary and grammar as about 2,500 to 1,900 BC. Professor Devaud (Devaud, 1924) made a systematic examination of this papyrus looking for 56 test words that appear in 30 papyri forming a chronological sequence from the 12th to the 18th Dynasty and placed this papyrus in the period before the Ebers Papyrus and possibly earlier than the Westcar Papyrus. Devaud considered it as possibly the oldest medical papyrus so far discovered. The text is much older than the manuscript which, by a modern assessment, is probably between the dates 1550-1500 BC.

The anatomical and medical knowledge displayed in this papyrus is quite remarkable. Before its study by Edwin Smith in the 19th century and the first brief publications by Breasted in 1920, Ancient Egyptian medicine was considered to be a potpourri of magical incantations and empirical recipes with no obvious basis resembling modern science. Then became available for study this very early document revealing an author versed in anatomy, surgery, and science. The author was obviously a learned anatomist, physician and surgeon, but also the inheritor of a previous canon of medical knowledge. The only known figure of this stature is Imhotep (Fig. 3) but this great architect and physician, our knowledge of whom is embellished by legend, belongs to an even earlier date than the text of this Edwin Smith Papyrus. It is likely that at the early time when Imhotep lived there were no continuous texts in any subject. The principal content of the document helps to characterise the author as a surgeon, versed in injuries and probably, since many of the injuries were those that occur in battle, an army surgeon. His alternative profession might have been a doctor concerned with a major construction site, a common state at this time in Egypt. What emerges clearly from reading the document is the practical 
value of the text to those concerned with treating and managing patients with injuries.

\section{The scribe and copyist of the Papyrus}

The ancient scribe (Fig. 4) who copied the document some 2,000 years after the first original has left in his work some clues as to his identity. Scribes were usually more than unlearned copyists but people of importance in an age when writing was an important restricted art. Many physicians were proud to bear, among other designations, the title of scribe. This transcriber, however, seemed to find his work difficult and may not have had any medical knowledge. $\mathrm{He}$ made many mistakes of omission and commission, some of which he corrected, in an ink of different colour, red on black and black on red. His difficulties in transcribing were evident and understandable, since he was contending with an unfamiliar subject in a language written some hundreds of years before. The end of the document is dramatic. The scribe stops abruptly in the middle of a case record, in the middle of a sentence, and in the middle of a word. Then at a place in the book which, from the contents so far, and judging from the remaining organs and limbs of the body to be described, would be about a third of the original textbook, he stopped writing and our document, as a surgical treatise, ends. On the reverse of the document the scribe added some totally different material and then the papyrus remained unaltered for some thousands of years to the present day.

\section{The discovery and form of the Papyrus}

Some notes of the discovery of this papyrus and its form (Fig. 5) and of the dates and periods of ancient Egypt are appropriate here. The papyrus was bought by Edwin Smith from a dealer in Luxor or Thebes in January 1862. Although its modern discovery is not documented, it was probably found in a tomb in the necropolis in Thebes (Siegerist, 1951). Edwin Smith seems swiftly to have recognised the medical nature and importance of the document, being one of the few persons then fluent in hieratic. He also saw that the outer folds of the papyrus had been removed, to give a more pristine appearance to the remainder, and, 2 months later, succeeded in tracing and acquiring these and adding them in a mutilated condition to his first purchase. The papyrus possibly came from the same tomb in Thebes in which was found the Ebers papyrus and the two papyri may have lain together for some hundreds of years. The papyrus is now unrolled and mounted between sheets of glass. It has a length of 4.68 metres and, as at least a column of writing is lost from the beginning, it originally measured over 5 metres. The roll has a height of from 32.5 to $33 \mathrm{cms}$. and is made of 12 sheets each of about $40 \mathrm{~cm}$ joined expertly to form the customary roll. The roll bears 17 columns of writing on the recto each from 28 to $29 \mathrm{cms}$ high and 18 to $27 \mathrm{~cm}$ wide. These form 377 lines. The material on the verso is quite unconnected and of no interest to us here. The date of the present document is judged, from features of the hieratic script, to be close to the age of the Ebers papyrus. The original text has vocabulary and grammar typical of Old Kingdom giving a date which can possibly be narrowed to between 2,600 


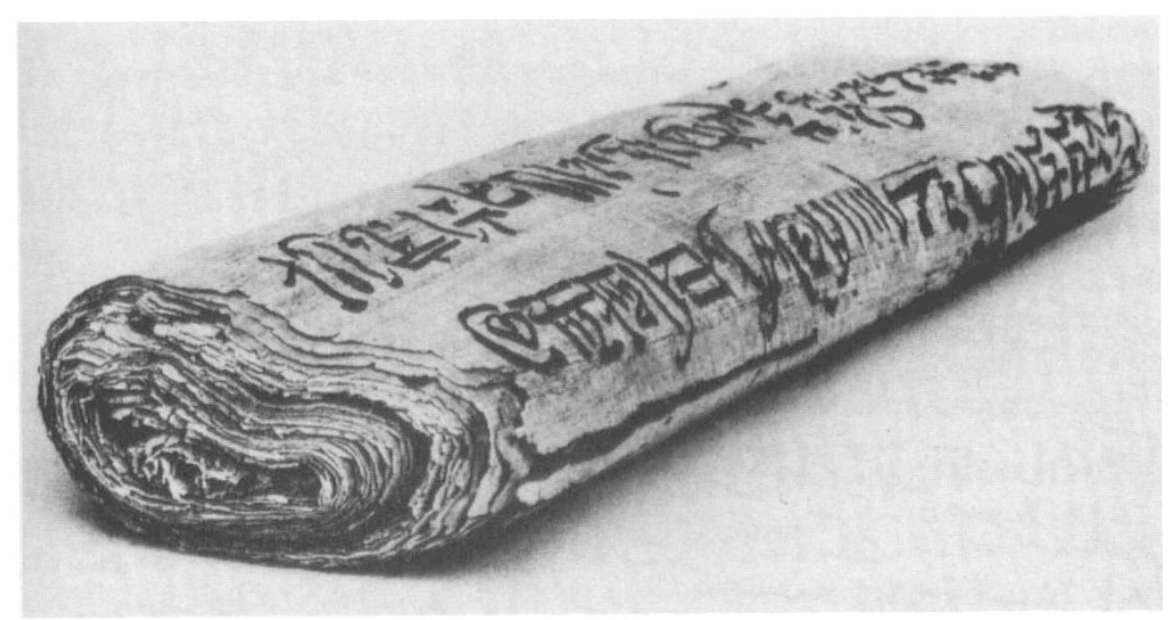

Figure 5 Egyptian Papyrus role. The figure depicts, not the Edwin Smith Surgical Papyrus, but the similar external appearance of the Chester Beatty Papyrus, No. 1 in the British Museum. The picture is taken from the frontispiece of The Chester Beatty Papyri, No. 1, by A.M. Gardner, printed by John Johnson at the Oxford University Press and published by Emery Walker Ltd.

and 2,150 BC. These dates are not precise and the technical language of this document would change more slowly than other written language. We come to an estimate of the age of the original text at over 4,000 years and the copy some hundreds of years, possibly 1,000 years, later.

\section{The medical and scientific content of the Papyrus}

We now come to an analysis of the medical subject of the papyrus and its scientific importance. Ignoring the added material on the verso, the document consists of the first part of a textbook on bodily injuries which are described systematically from head to toe, except the scribe did not reach the abdomen and lower limbs. The book consists of a series of case reports of which the first 27 deal with injuries to the head. Then come 6 cases of injuries to the throat and neck of great interest to us, 2 cases of injury to the clavicle, and 12 cases with injuries to the humerus, sternum, and shoulders. The last case, case 48 , is for us the most interesting dealing with the spine and here in the middle of the case the scribe breaks off neglecting, for some urgent pressing business, to copy what presumably were further cases of injury to the spine, chest, abdomen, and lower limbs. Our loss is immense but we must thankfully consider what we are permitted to see of medicine 2,500 BC.

Six cases concern us, and these are cases 29 to 33 (Fig. 6) and case 48 . All are similar in form with a title, a description of the examination of the case, followed by a statement of the diagnosis, and ending with recommendations for treatment, if treatment is indicated, otherwise the unfavorable outcome is stated. Then follows a commentary later than the original, added by way of explanation by a scribe probably with medical knowledge. The translation of Breasted of these 6 cases will now be quoted. Words in brackets ( ) were added by Breasted to give fluency, and the cases were numbered by him. Words in square brackets [] 


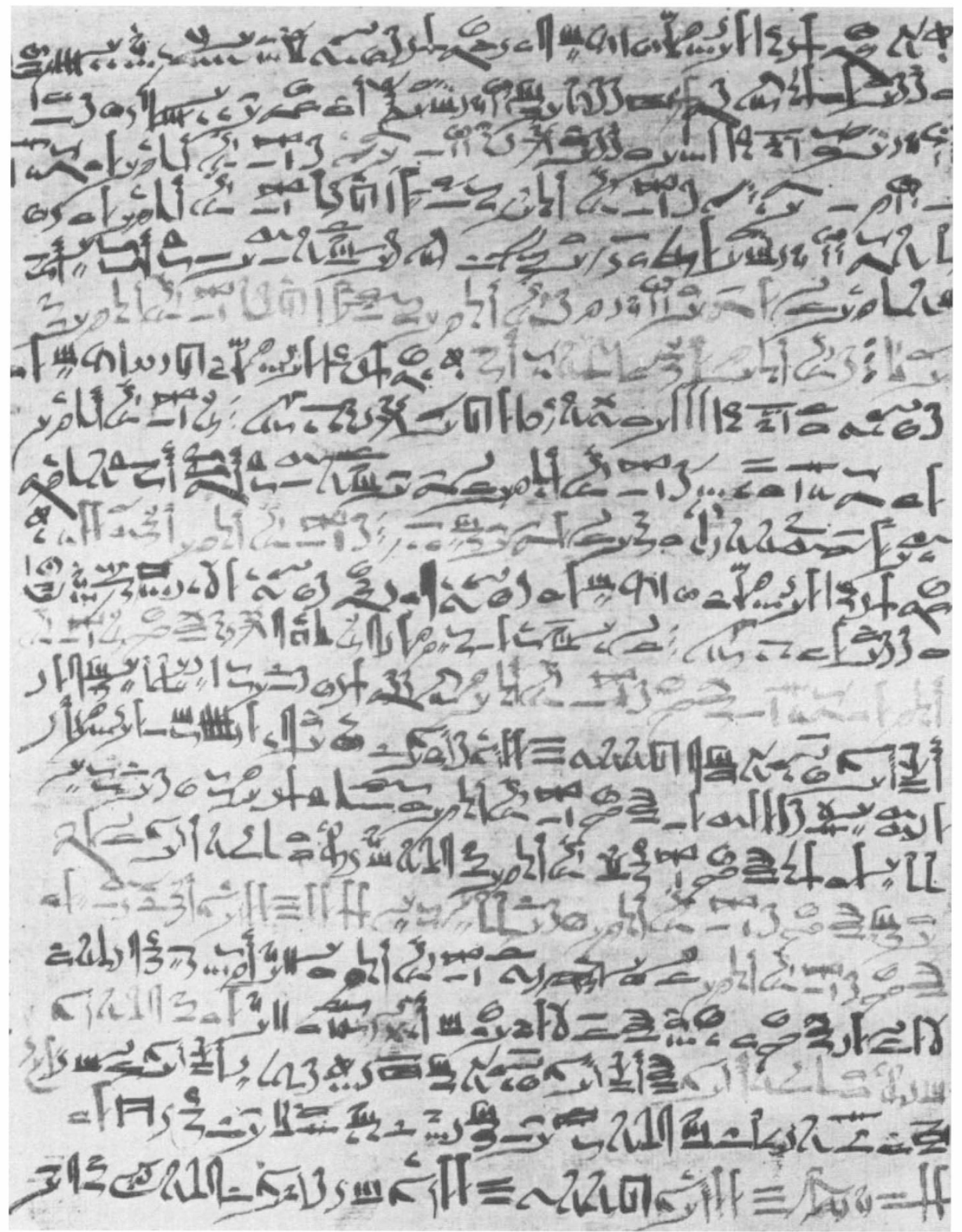

Figure 6 Column $\mathrm{X}$ of the Edwin Smith Surgical Papyrus, written in hieratic script, and describing cases 29-31. The writing proceeds from above down and from right to left. Those parts of the script which appear lighter were entered in red to denote headings of the text. This picture (plate V) and that in Figure 7 (plate XVII) are taken from Breasted J.H. (1930).

were 'restored' by Breasted who judged them to have been originally present in the document. I have then added to each case my own comments, under the heading 'modern commentary'. The magnificent work of Breasted gave us a transliteration into hieroglyphic and a detailed translation with copious notes on the exact meaning of the original. Professor Breasted had the assistance of Dr 
Arno B. Luckhardt who gave opinions on the medical interpretation of the cases which were incorporated into notes on the cases. Subsequently other Egyptologists have studied the papyrus and a new translation was made into German (Westendorf, 1966). Having read these comments it is clear that on many points we cannot be sure of the meaning of the original author, and whilst partly this is a lack of knowledge of the medical vocabulary of Ancient Egyptian, there is also the problem posed by a copy, itself possibly copied from a whole sequence of copies extending back some hundreds of years to the original. With these limitations very much in mind, I have, in my added comments, analysed the 6 cases from the point of view of a doctor and neuropathologist familiar with cases of spinal cord injury.

\section{Six selected case reports of spinal cord injuries}

\section{Case 29: Instructions concerning a gaping wound in a vertebra of his neck}

Examination: If thou examinest a man having a gaping wound in a vertebra of his neck, penetrating to the bone, (and) perforating a vertebra of his neck; if thou examinest that wound, (and) he shudders exceedingly, (and) he is unable to look at his two shoulders and his breast.

Diagnosis: Thou shouldst say concerning him: '(One having) a wound in his neck, penetrating to the bone, perforating a vertebra of his neck, (and) he suffers with stiffness in his neck. An ailment with which I will contend.'

Treatment: Thou shouldst bind it with fresh meat the first day. Now afterward moor (him) at his mooring stakes until the period of his injury passes by.

Modern commentary: This must surely be a wound sustained in battle and inflicted by a spear or similar pointed weapon. There is an open (gaping) wound with penetration of the weapon to the vertebra which is injured. However, the spinal cord is not injured since there was 'stiffness' of the neck but no paralysis or sensory loss as described in subsequent cases. The surgeon considered the prognosis favourable and the wound was to be bound up with fresh meat. Spinal and orthopaedic surgeons please note that the phrase 'moor him at his mooring stakes' does not mean skeletal traction but was an idiom meaning to continue the original treatment without further prescription.

\section{Case 30: Instructions concerning a sprain in a vertebra of his neck}

Examination: If thou examinest a man having a sprain in a vertebra of his neck, thou shoulds say to him: 'Look at thy two shoulders and thy breast.' When he does so, the seeing possible to him is painful.

Diagnosis: Thou shouldst say concerning him: 'One having a sprain in a vertebra of his neck. An ailment which I will treat.'

Treatment: Thou shouldst bind it with fresh meat the first day. Now afterward thou shouldst treat (with) ymrw (and) honey every day until he recovers.

Ancient Commentary: As for: 'A sprain,' he is speaking of a rending of two members, (although) it ( $=$ each) is (still) in its place.

Modern Commentary: The form of this surgical textbook is to proceed in each part of the body, which is serially dealt with, from slight to severe injuries. This case is more serious than that preceeding since two vertebrae are involved. The translation uses the word 'sprain' and the Egyptian equivalent is only known in this papyrus, where, however, it occurs several times. The writer of the ancient commentary was not entirely familiar with the word 'sprain' but helps us to a modern diagnosis of a fracture or a fracture 
dislocation of the spine without displacement. There is no mention of an open wound. A favourable prognosis is given with a recommended treatment.

\section{Case 31: Instructions concerning a sprain in a vertebra of (his) neck}

Examination: If thou examinest a man having a dislocation in a vertebra of his neck, shouldst thou find him unconscious of his two arms (and) his two legs on account of it, while his phallus is erected on account of it, (and) urine drops from his member without his knowing it; his flesh has received wind: his two eyes are blood-shot; it is a dislocation of a vertebra of his neck extending to his backbone which causes him to be unconcious of his two arms (and) his two legs. If, however, the middle vertebra of his neck is dislocated, it is an emissio seminis which befalls his phallus.

Diagnosis: Thou shouldst say concerning him; 'One having a dislocation in a vertebra of his neck, while he is unconcious of his two legs and his two arms, and his urine dribbles. An ailment not to be treated.'

Ancient Commentary A. As for: 'A dislocation (wnh) in a vertebra of his neck, 'he is speaking of a separation of one vertebra of his neck from another, the flesh which is over it being uninjured; as one says, 'It is wnh,' concerning things which had been joined together, when one has been severed from another.

Ancient Commentary B. As for; 'It is an emissio seminis which befalls his phallus,' (it means) that his phallus is erected (and) has a discharge from the end of his phallus. It is said: 'It remains stationary' ( $M N$ s'w), when it cannot sink downward (and) it cannot lift upward.

Ancient Commentary C. As for: 'While his urine dribbles,' it means that urine drops from his phallus and cannot hold back for him.

Modern Commentary: This is one of the most interesting cases in the whole papyrus and displays a knowledge of anatomy, physiology, neurology, and pathology. The ancient surgeon notes that dislocation of the vertebrae in the neck is accompanied by loss of sensation (unconcious of) of the arms and legs, lack of control of passage of urine, erection of the phallus and ejaculation of semen. The explanation in the ancient commentary of a dislocation without an open wound is remarkably clear. The description in Examination has aroused much speculation. It seems to indicate that the author distinguished between spinal injuries at two sites one possibly low down in the cervical spine associated with a cord lesion and another type affecting the 'middle' cervical vertebrae and causing penile erection and ejaculation. Treatment is not recommended which opinion is stated immediately after the description of quadriplegia with bladder incontinence. The phrase 'his flesh has received wind' probably means abdominal distention, and the phrase 'his eyes are blood shot' refers to vasodilation due to paralysis of vasomotor control.

\section{Case 32: Instructions concerning a displacement in a vertebra of his neck}

Examination: If thou examinest a man having a displacement in a vertebra of his neck, whose face is fixed, whose neck cannot turn for him, (and) thou shouldst say to him: 'Look at thy breast (and) thy two shoulders,' (and) he is unable to turn his face that he may look at his breast (and) this two shoulders, (conclusion follows in diagnosis).

Diagnosis: Thou shouldst say concerning him: 'One having a displacement in a vertebra of his neck. An ailment which I will treat.'

Treatment: Thou shouldst bind it with fresh meat the first day. Thou shouldst loose his bandages and apply grease to his head as far as his neck, (and) thou shouldst bind it with ymrw. Thou shouldst treat it afterward [with] honey every day, (and) his "relief" is sitting until he recovers. 
Ancient Commentary. As for: 'A displacement in a vertebra of his neck,' he is speaking concerning a sinking of a vertebra of his neck [to] the interior of his neck, as a foot settles into cultivated ground. It is a penetration downward.

Modern Commentary: This fourth case describes cervical spinal injury with displacement of a vertebra but not apparently with involvement of the spinal cord. A good prognosis is given and treatment is recommended. The ancient scribe made in this case an interesting copying error. Beginning line four he omitted the customary 'Thou shouldst say concerning him' and then, observing his error, inserted the words at the top of the column. At the left end of line three he placed, in red ink, a cross, creating the first example of the use of the asterisk.

\section{Case 33: Instructions concerning a crushed vertebra in his neck}

Examination: If thou examinest a man having a crushed vertebra in his neck (and) thou findest that one vertebra has fallen into the next one, while he is voiceless and cannot speak; his falling head downward has caused that one vertebra crush into the next one; (and) shouldst thou find he is unconcious of his two arms and his two legs because of it, (conclusion follows in diagnosis).

Diagnosis: Thou shouldst say concerning him: 'One having a crushed vertebra in his neck; he is unconcious of his two arms (and) his two legs, (and) he is speechless. An ailment not to be treated.'

Ancient Commentary A. As for: 'A crushed vertebra in his neck,' he is speaking of the fact that one vertebra of his neck has fallen into the next, one penetrating into the other, there being no movement to and fro.

Ancient Commentary B. As for: 'His falling head downward has caused that one vertebra crush into the next, 'it means that he has fallen head downward upon his head, driving one vertebra of his neck into the next.

Modern Commentary: This case is the most serious so far. A man has fallen head downwards and suffered a crush fracture of a cervical vertebra with compaction of one vertebra into the next. There is no abnormal movement but spinal cord damage is evident. The brain is affected (speechless) and possibly there is vertebral artery obstruction or an accompaning head injury. Prognosis is bad and no treatment is indicated.

\section{Case 48: Instructions concerning a sprain of a vertebra [in] his spinal column}

Examination: If thou examinest [a man having] a sprain in a vertebra of his spinal column, thou shouldst say to him: 'Extend now thy two legs (and) contract them both (again).' When he extends them both he contracts them both immediately because of the pain he causes in the vertebra of his spinal column in which he suffers.

Diagnosis: Thou shouldst say concerning him: 'One having a sprain in a vertebra of his spinal column. An ailment which I will treat.'

Treatment: Thou shouldst place him prostrate on his back; thou shouldst make for him...

(Here the scribe ceased copying in the middle of a word and the document ends.)

Modern Commentary: The great interest of this last incomplete case report is swamped by our regret that we have none to follow and have lost descriptions of many thoracic, lumbar-sacral, and possibly cauda equina lesions, doubtless with many interesting observations of anatomy, physiology, neurology, and neuropathology. What survives here is of remarkable interest. A case of spinal injury is being examined, and the patient is being asked to extend and flex the legs. The case is an incomplete spinal cord lesion, a 




Figure 7 Case 48 and the end of the Papyrus. The last intelligible phrase is 'Thou shouldst make for him! The document ends in the middle of a word and the last character has been drawn twice, the first time with insufficient ink.

good prognosis is stated, and an interesting treatment, devised 5,000 years ago is about to be described when the document ends (Fig. 7).

\section{Ancient Egyptian medicine}

The Edwin Smith Surgical Papyrus must be considered in the setting of our current knowledge of ancient Egyptian medicine. Doubtless the evidence that has survived to the present day is a small part of that which existed in the long span of thousands of years. Yet such has been the remarkable preservation of countless inscriptions on stone and, with even greater good fortune, the survival of many papyri, that our knowledge of the way of life in ancient Egypt transcends almost any area and people of this antiquity. Our knowledge of ancient Egyptian physicians and their work is as extensive as any other sphere of activity in this period and this region, since physicians enjoyed a high status and their work and knowledge was prized, particularly by the rulers. Jonckheere (1958) in his monograph on the doctors of ancient Egypt lists not only the individual doctors but can sometimes identify their specialty of practice. Much information about the importance and place in society of the doctors can be inferred from the various inscriptions portraying doctors. For a general account the popular works of Ghalioungui $(1963,1973)$ and Leca $(1971)$ are recommended, and the earlier text of Dawson (1929) remains of interest.

For knowledge of the details of medical practice we must study the surviving medical papyri, later than inscriptions on stela, but sometimes copying and recording a much earlier medical canon of knowledge. There are some eight ancient medical Egyptian Papyri and for a summary of these the accounts of Caton (1904), Sigerist (1951) and Leake (1952) are recommended. These eight documents will be listed here with very brief notes: 1 . Kahun. (1,900 BC). A medical treatise from the Middle Kingdom dealing with diseases of women and also of animals. Published and translated by Griffiths in 1898 and now in London. 2. Edwin Smith, the subject of this paper. Now in New York. 3. 
Ebers. (1,550 BC). A most important document recommending drugs and therapies and dealing with diverse diseases many quite obscure as to their modern equivalent. Now in Leipzig. 4. Hearst. (1,550 BC). An incomplete document dealing with many prescriptions, not easily set in any comprehensible order. Now in Berkeley, USA. 5. Erman. (1,550 BC). A medical papyrus dealing mainly with infants and the conduct of childbirth. Now in Berlin. 6. London. (1.350 $\mathrm{BC})$. A later papyrus combining medical and magical remedies and containing numerous recipes. A poor copy by a scribe not familar with his subject matter. In the British Museum, London. 7. Berlin. (1,350 BC). A poor description of several diseases and many prescriptions some similar to or identical with those in the Ebers and Hearst papyri. In Berlin. 8. Chester Beatty. $(1,200 \mathrm{BC})$. An incomplete medical treatise dealing with conditions of the anus. In London.

\section{Conclusion}

From the extracts from the Edwin Smith Surgical Papyrus given here, which quote 6 cases of spinal injuries, and the brief descriptions above of the other medical papyri, one can appreciate the quality of the Edwin Smith papyrus, only rivalled in importance by the Ebers papyrus. Partly this is due to the subject matter which deals with anatomy and surgical trauma, and which are easier to describe lucidly than miscellaneous medical diseases. Also the document consists mainly of specialised case reports in which one readily grasps the significance of the traumatic state which may be identical to a particular penetrating wound or injury seen today. Again we regret that the document is incomplete, since the fragment that has survived is so informative compared to the other surviving medical papyri. Our conclusion is that at the date of copying of the Edwin Smith surgical papyrus, and the much earlier date of the lost original, an understanding of scientific medicine, including anatomy and physiology, had developed and this was being applied to the care of patients, guided by a knowledge of prognosis and the efficacy of various treatments. We also have in this first medical textbook evidence of the systematic instruction of future generations. Thus the document provides a date when the academic profession of medicine was in existence.

\section{Acknowledgements}

The author records his gratitude for the use of the Wellcome Library, London, and the Bodleian Library, Oxford, and for advice and help to Professor J.R. Baines and the staff of the Griffith Institute of the Ashmolean Museum of Art and Archaeology, Oxford.

\section{References}

AdAms AL 1870 Notes of a naturalist in the Nile Valley and Malta. Edmonston and Douglas, Edinburgh, pp. 56-58.

Breasted JH 1922a 'The Edwin Smith Surgical Papyrus, 'Quart. Bull. New-York Historical Society, 1922, 6:1-31.

BREASTED JH 1922b 'The Edwin Smith Surgical Papyrus, some preliminary observations,' Recueil d'etudes Egypt, dediees a la Memoire de Jean-Francois Champollion, Paris, pp. 385-429. 
BReASted JH 1930 Edwin Smith Surgical Papyrus, in Facsimile and Hieroglyphic Transliteration with Translation and Commentary, 2 vols. University of Chicago Oriental Institute Publications, Chicago.

Caton R 1904 Iem Hotep and ancient egyptian medicine. Part 1. of the Harveian Oration, delivered before the Royal College of Physicians on 21.6.04. CJ Clay \& Sons, London.

DAwsON WR 1929 Magician and Leech. Methuen, London.

DÉvaUd E 1924 L'âge des papyri égyptiens hiératiques. Paris.

Ghalioungui P 1963 Magic and medical science. Hodder \& Stoughton, London.

Ghaliounguip 1973 2nd. ed. The house of life, magic, and medical science in ancient Egypt. BM. Israel, Amsterdam.

JoNCKHEERE F 1958 Les Médecins de l'Égypte Pharaonique, Fondation Egyptologique de la Reine Elisabeth, Bruxelles.

LEAKE CD 1952 The old egyptian medical papyri. University of Kansas Press, Kansas.

LECA A-P 1971 La medecine egyptienne au temps des Pharons. Roger Dacosta, Paris.

SIEgERIST HE 1951 A History of Medicine. Vol.1: Primitive and archaic medicine. Oxford University Press, Oxford.

WESTENDORF W 1966 Papyrus Edwin Smith. Ein medizinisches Lehrbuch aus dem alten Aegypten. Hans Huber, Bern and Stuttgart. 